\title{
HRVATSKO PROLJEĆE U GOSPIĆU
}

Ivica MATAIJA

Državni arhiv u Gospiću

Gospić, Hrvatska

Sanja VRCIĆ-MATAIJA

Sveučilište u Zadru

Odjel za nastavničke studije u Gospiću

Gospić, Hrvatska
UDK: 323.1(497.5 Gospić)“1971“

DOI: $10.21857 / \mathrm{mjrl3u}$ q 39

Izvorni znanstveni rad

Prihvaćeno: 19. ožujka 2020.

U radu se analiziraju društvene i političke prilike u Gospiću za vrijeme hrvatskog proljeća. Posebna je pozornost posvećena djelovanju lokalnih organizacija Saveza komunista kao kreatora sveukupnog društvenog života koji se u tom razdoblju suočio s brojnim izazovima, a čije su se odluke, utemeljene na političkom načelu demokratskog centralizma, odrazile na brojne ustanove i pojedince koji su zauzimali važno mjesto u tadanjem društvenom i kulturnom životu Gospića. Među njima posebno ističemo gospićki ogranak Matice hrvatske koji se suočio s osudom i zabranom djelovanja, a neki njegovi vodeći članovi bili su izloženi političkim i sudskim progonima.

Ključne riječi: hrvatsko proljeće, Savez komunista, Gospić, Matica hrvatska, Analiza, jezična pitanja.

\section{UVOD}

Nakon političkih i manjim dijelom jezičnih previranja koje je na gospićko područje donijela Deklaracija o nazivu i položaju hrvatskog književnog jezika 1967. god., ${ }^{1}$ a koja su relativno kratko trajala, hrvatsko je proljeće 1971. pokrenulo u gospićkoj javnosti, ali i u političkim, pravosudnim, obavještajnim, prosvjetnim i kulturnim institucijama, procese s mnogo snažnijim odjecima i posljedicama. Pitanja na koja Savez komunista na gospićkom području nije imao odgovora dva i pol desetljeća i problemi koji su sustavno ignorirani, a uvodno aktualizirani 1967., ponovno su oživjeli u okviru nacionalnih reformskih procesa u hrvatskoj politici, kulturi i društvu početkom sedamdesetih godina. Gospićko je društvo, nakon Drugog svjetskog rata izgrađeno na neriješenim

1 Usp. Ivica Mataija i Sanja Vrcić-Mataija, Odjeci Deklaracije o nazivu i položaju hrvatskog književnog jezika na području Gospića, u: Zadarski filološki dani 7, Zbornik radova, ur. Rafaela Božić, Sandra Hadžihalilović i Josip Lisac, Zadar, 2019., 49 - 64. 
nacionalnim pitanjima, ${ }^{2}$ unutarnjoj podijeljenosti na pobjednike i poražene, podobne i nepodobne, ${ }^{3}$ živjelo u stanju stalne napetosti. Gospodarski, komunalni i infrastrukturni rast $^{4}$ započet pedesetih i šezdesetih godina vrlo se brzo suočio s ozbiljnom krizom ${ }^{5}$ koja je, uz političke razloge, bila povodom intenzivnog odlaska radno sposobnog stanovništva u zapadnoeuropske i prekooceanske zemlje. U Ličkim novinama br. 13 od 1. 7. 1971. u članku naslovljenom „Više pažnje zaposlenima u inozemstvu“ doneseno je izvješće sa savjetovanja Općinske konferencije SSRNH svih pet ličkih općina posvećeno problemima migracije radne snage u inozemstvo, rasvjetljavanju razloga i traženja načina njihova povratka u domovinu. Prema objavljenoj statistici, ukupan broj zaposlenih 31. 12. 1970. na području Općine Gospić (zaokružene vrijednosti) iznosio je 5600, dok je 31. 12. 1971., 2965 osoba s područja Općine bilo na privremenom radu $u$ inozemstvu, što je predstavljalo 51,5 \% ukupno zaposlenih na području Općine. Među tom populacijom i onom koja je s gospićkog područja izbjegla nakon rata te u njihovim obiteljima koje su ostale u domovini, lokalni je SK dosljedno tražio i neprijatelje samoupravnog društva i tekovina oslobodilacke revolucije.

2 O važnosti nacionalnih pitanja i pokušaju njihovih rješavanja unutar SK svjedoči i djelovanje Komisije za međunacionalne odnose koja je, osnovana nakon 8. kongresa SK, pri Centralnom komitetu SKJ svoju prvu sjednicu održala 5. 6. 1965. „Primarni zadatak te komisije bile su opservacije i diskusije svih određujućih društvenih faktora za razvoj međunacionalnih odnosa kako bi Partija na vrijeme mogla reagirati na nacionalističke ekscese u društvu.“ Iva Lučıć, Političke kontroverze o popisu stanovništva 1971. godine, u: Hrvatsko proljeće 40 godina poslije, Zbornik radova, ur. Tvrtko Jakovina, Centar za demokraciju i pravo Miko Tripalo, Zagreb, 2012., 225 - 243.

Tih su prilika sve jasnije 1967. postali svjesni i gospićki komunisti. Izvješća lokalne organizacije SK govore o problemima prijama u SK onih mladih za koje „se ponekad prenaglašava značaj kako su se određenom drugu koji se predlaže u SK držali roditelji u toku NOB-a. Takva shvatanja pripadaju prošlosti (...). (Hrvatska - Državni arhiv u Gospiću, Gospić (dalje HR-DAGS), fond 93: Općinski komitet SK Gospić, 1960. - 1987. - Informacija br. 1. 6. 1967.

4 Iz novinskih članaka objavljenih u XVII. godištu Ličkih novina vidljivo je da je na području Općine Gospić bilo neriješenih komunalnih i infrastrukturnih problema. Stambena izgradnja odvijala se sporo, ceste su bile u lošem stanju, kanalizacijski problemi vrlo izraženi. U br. 12 Ličkih novina na 1. str. objavljen je naslov Dokle zaostajanje Like u kojem se kao najveći problemi ističu neizgrađena komunalna infrastruktura (ceste koje povezuju naselja, vodoopskrba - s nestancima vode suočilo se naselje Lički Osik, a npr. Bužim je bio bez vodovoda), o čemu svjedoči članak „Žedna Lika“, Ličke novine, br. 21., 1. 11. 1971.

5 O tim se problemima govorilo i na 3. sjednici Općinske konferencije SKH Gospić na kojoj je slab uspjeh Akcionog programa Općine Gospić pripisan pojedinim društveno-političkim organizacijama, radnim organizacijama i pojedincima. Zaključili su da će napraviti analizu o uzrocima koji su uvjetovali ovakovo stanje i koji su doprinijeli da se Akcioni program nije realizirao. Zbog lošeg financijskog poslovanja, koje traje od 1968., 1. 4. 1971. uvedena je prinudna uprava u GP Lika iz Gospića. Prinudna je uprava uvedena i Ugostiteljskom poduzeću Velebit iz Ličkog Osika zbog ogromnih financijskih gubitaka. 
Očito su partijske strukture na gospićkom području, kao vodeće, idejne $i$ usmjeravajuće snage, redovito oportuno reagirale na društvene procese, svjesne da Partija ne dopušta da ikoji njezin član radi nešto u suprotnosti s njezinom političkom linijom, te $s$ određenim, ali dosljednim kašnjenjem i na tragu doktrine demokratskog centralizma ugledale se i tražile direktive iz centara političke moći (Predsjedništvo Saveza komunista Jugoslavije, Centralni Komitet Saveza komunista Hrvatske). Na taj su način čuvali političke pozicije svojih čelnika koji su očito imali problema s artikuliranjem lokalnih političkih interesa i stavova. O tome je, na dvodnevnom savjetovanju Privredno-političkog aktiva Like održanom u Plitvicama 18. i 19. 12. 1970., govorio i tadašnji predsjednik Sabora Jakov Blažević koji je istaknuo da „na ovoj regiji vi ste slabo organizirani. Vi još niste uspjeli, na primjer u poljoprivredi razraditi jednu koncepciju širu regionalnu ovu ličku (...) a mi trebamo regionalnu, mi trebamo ličku koncepciju (...) baš zbog sporog razvoja, te koncepcije, te organizacije, i integracije, zbog toga što se ispred privrednih organizacija isprečuju općinske skupštine, isprečuju organizacije Saveza komunista bez programa, bez toga mi smo umrtvili privredne organizacije (...) Da to ne ide što je Srbin ovdje, Hrvat ondje, što je ovo srpski kraj, što je ono hrvatski kraj, pa se onda počne brojiti koliko u jednoj organizaciji ima Srba a ima Hrvata, koliko je ove godine potrošeno sredstava u srpskom ili hrvatskom kraju (...).“6

O političkim, sigurnosnim, pravosudnim, medijskim, kulturnim i jezičnim prilikama toga doba u Gospiću svjedoči sačuvano arhivsko gradivo, novinski članci objavljeni u Ličkim novinama i dostupna memoarska građa.

\section{DRUŠTVENO-POLITIČKE PRILIKE U GOSPIĆU U OZRAČJU HRVATSKOG PROLJEĆA}

Političke prilike u Gospiću 1971. obilježene su raspravama o gospodarskim problemima, popisu stanovnika, ${ }^{7}$ nacionalizmu, ${ }^{8}$ liberalizaciji, ${ }^{9}$ krizi u lokalnom

6 Brži razvitak Like, Ličke novine, br. 1 (425), 1. 1. 1971.

7 „Punu godinu dana prije izvedbe službenog popisa, sastanci Saveza komunista pretvorili su se u dinamičan laboratorij za isprobavanje i utvrđivanje buduće matrice strukturiranja društva na području SFRJ. Diskusije koje su se vodile (...) reflektirale su ponajviše političke interese republičkog rukovodstva te na taj način otkrivale instrumentalnu i ispolitiziranu dimenziju koju je popis imao. Kao glavne točke dnevnog reda bile su diskusije o definiciji ponajviše triju kategorija: Musliman, Jugoslaven i tzv. regionalne kategorije, čiji se finalni oblik u saveznom popisnom formularu najprikladnije može opisati kao rezultat jednogodišnjeg političkog i diskurzivnog djelovanja unutar političkog vrha.“ I. Lučıć, Političke kontroverze o popisu stanovništva 1971. godine, 231. Konačan ishod jednogodišnje rasprave bilo je dodavanje nove kategorije „Musliman 
SK i o predloženim ustavnim promjenama za koje su lički političari držali da su u politički život unijele do tada neviđenu živost ${ }^{10}$. Ta je živost bila u tom razdoblju vrlo intenzivna na području cijele Hrvatske, a bila je potaknuta 10. sjednicom CK SKH održanom od 15. do 17. siječnja 1970., koja je ujedno i prva partijska sjednica koju je prenosila televizija i na taj način otvorila, do tada zatvorene, partijske rasprave javnosti. „Ta je sjednica, zapravo, bila odgovor na akciju unitarista u vrhu savezne administracije, koja se već dulje vrijeme vodila protiv Tita i protiv hrvatskoga republičkoga i partijskog vodstva. Iako je ispunila Titova očekivanja, 10. sjednica CK SKH se zapravo pretvorila u sjednicu oblikovanja

u nacionalnom smislu“ i zadržavanje kategorije Jugoslaven kao političke identitetske, a ne nacionalne odrednice. Zanimljivo je u tom smislu pratiti udio Jugoslavena na području Općine Gospić. Naime, prema popisu stanovnika udio Jugoslavena u ukupnom broju stanovnika popisne 1961. iznosio je 0,32 \%, 1971. 1,7 \%, a 1981. 9 \%, a na području naselja Gospić: 1961. 0,94 \%, 1971. 4,17 \% i 1981. 17,04 \%. „Socijalistički savez posebno naglašava da se prilikom samog akta popisa svakom građaninu osigurava potpuna sloboda i sigurnost u izjašnjavanju uopće, a osobito o njegovoj nacionalnoj, odnosno etničkoj pripadnosti.“ Počeo popis stanovništva, Ličke novine, br. 7., 1. 4. 1971. Općinski je komitet SK Gospić procijenio da je popis stanovništva utjecao na pogoršanje političkih prilika u Općini i uznemirio građane u obiteljima miješanih brakova na tragu javnih stavova da je jugoslavenstvo kao nacionalna deklaracija izraz unitarizma, držeći da su se na taj način kršila prava i slobode građana (Hrvatska - Državni arhiv u Gospiću, Gospić, fond 93: Općinski komitet SK Gospić, 1960. - 1987. Analiza političkog stanja na području Općine Gospić u periodu od 1. 1. 1971. do 1.3. 1972. (dalje Analiza, 1972.)

8 „Nacionalizam je kao politička, kulturna i društvena pojava u razdoblju socijalističke Jugoslavije od vladajućega režima bio anatemiziran i stigmatiziran kao društveno i politički neprihvatljiv oblik ponašanja, djelovanja i razmišljanja. To je normalno i očekivano, s obzirom na to da je taj režim javno propagirao internacionalizam, ponajprije kroz službenu ideologiju a onda i kroz, tada već politički potrošenu, sintagmu o bratstvu i jedinstvu. Bilo kakvo iskazivanje domoljublja, skrbi za nacionalnu kulturu, jezik, povijest, pjevanje domoljubnih pjesama, nošenje nacionalnih obilježja i znakovlja bez socijalističkih simbola i sl., proglašavano je nacionalizmom. "Darko Dukovs KI, Istra i Rijeka u Hrvatskome proljeću, Zagreb, 2007., 33.

9 O liberalizaciji hrvatskog društva prije i tijekom hrvatskoga proljeća usp. Josip Minaljević, Liberalizacija 1960-tih godina - podloga hrvatskoga proljeća, u: Hrvatska i hrvatsko proljeće 1971., Zbornik radova, ur. Igor Zidić, Zagreb, 2017., 263 - 277.

10 Rasprava o amandmanima objavljena u članku „Široka rasprava o amandmanima - Javna rasprava o ustavnim amandmanima u Općini Gospić" Ličkih novina (br. 12., 15. 6. 1971.) pobudila je velik interes građana te je bila jedna od najmasovnijih i najuspješnijih političkih akcija tog vremena. Objavljeno je da je održano 56 javnih rasprava po naseljima i selima i 31 rasprava u poduzećima i ustanovama na kojima je nazočilo 9000 građana, a samo predavanju Mike Tripala, održanom u Gospiću 13. 4., nazočilo je 1500 stanovnika Gospića. Kasnije se, u prvoj polovici 1972., takav stav drastično promijenio pa je partijskim analizama taj interes proglašen razdobljem najintenzivnijeg divljanja nacionalističkih strasti. „Poznat je istup Mike Tripala u Gospiću pred velikom skupom građana, gdje su se okupili ne samo aktivisti, već i oni koji se nikad nisu našli na nijednom političkom skupu ili političkoj manifestaciji na ovom području od oslobođenja do danas, a poslije čijeg boravka su se počeli masovnije javljati ekscesi i nacionalistički istupi.“ Analiza, 1972., 6. 
političke platforme o položaju Hrvatske u Jugoslaviji (...) pokušaj afirmacije i uspostavljanja 'hrvatske nacionalne politike'. Ona je početak središnje faze Hrvatskoga proljeća na kojoj se do kraja osudilo unitarističko jugoslavenstvo i savezni centralizam. (...) Deseta sjednica je pokrenula lavinu diskusija u najširim slojevima stanovništva. Razgovaralo se o daljem razvitku Jugoslavije, Hrvatske, međunarodnim odnosima, opasnosti od nacionalizma i unitarizma kao i o daljem razvitku samoupravljanja." ${ }^{11}$

$\mathrm{Na} 20$. sjednici Centralnog komiteta SKH, održanoj 13. i 14. 5. 1971., o stanju u Lici govorio je Budimir Korica, predsjednik Međuopćinske konferencije SK za Liku i član Centralnog komiteta SKH, koji je istaknuo kako je „novi kurs politike SK u narodu izvrsno prihvaćen i da je narod postao zainteresiran za politiku više nego ikad, da su mnoge do jučer tabu teme danas detabuizirane, o njima se raspravlja bez zaziranja, otvoreno (...) Mislim da u tom pogledu najviše imamo problema upravo kod pojedinih partijskih rukovodilaca i članova Saveza komunista koji nemaju sposobnosti da ovoga časa sagledaju probleme u svojoj sredini. U nedostatku sposobnosti da to učine, oni "uvoze“ probleme. (...) Ozbiljnijeg nacionalističkog istupa u onom smislu da bi to izazvalo određene sukobe itd. u ovoj sredini nije bilo ili mi bar za njega ne znamo. (...) Jedan problem, koji je zapažen u političkoj praksi - jeste da mi zapravo u političkim rukovodstvima općinskim pa i mjesnim itd., nemamo često puta one ljude koji znaju na terenu ocijeniti kakva je politička situacija kod njih, nisu u stanju razlikovati što je politički bitno, mislim, što je ispravno na ovom kursu, od onoga što se pod tom firmom našega kursa pojavljuje u biti kao neprijateljsko." ${ }^{2}$ Inače, u tom se razdoblju gospićki SK suočio s ozbiljnim problemima o kojima je raspravljano i na Općinskoj konferenciji na kojoj je Petar Kuprešanin, sekretar Općinskog komiteta, ${ }^{13}$ naveo da se dio članstva pasivizirao i samovoljno napustio SK. Tada je Općinska organizacija brojila 1874 člana „što je u odnosu na stanje od prije nekoliko godina manje za blizu 1000 članova“. ${ }^{14}$ Kuprešanin je naveo da je krajnje vrijeme „da se zavede apsolutni red i ostvari čistoća prije svega unutar svojih redova i da se SK oslobodi kolebljivaca, malodušnika i slučajnih svojih suputnika (...)

11 D. Dukovs KI, Istra i Rijeka u Hrvatskome proljeću, 40 - 41.

12 Narod prihvaća promjene, Ličke novine, br. 11., 1. 6. 1971.

$13 \mathrm{Na}$ izbornoj Općinskoj konferenciji SKH Gospić, održanoj 17. 7. 1970., za predsjednika Konferencije izabran je Petar Barun, šumarski inženjer iz Šumarije Perušić, za njegova zamjenika Jovo Lazić, a u Općinski komitet Joso Bašić, Jovan Bobić, Josip Brkljačić, Jovica Ciganović, Nevo Domines, Petar Kuprešanin, Karlo Marković, Milan Obradović, Svetozar Orlović, Milan Pantelić, Grga Pavletić, Ivan Šop, Mate Tomljenović, Đuro Uzelac i Martin Vidović.

14 Zašto neki napuštaju Savez komunista, Ličke novine, br. 13, 1. 7. 1971. 
i da se široko otvore vrata za ulazak u SK onih progresivnih i socijalistički orijentiranih snaga" ${ }^{15}$ koje su po njemu trebale doći iz redova radništva, seoske omladine i progresivnih i naprednih intelektualaca. Brojni društveni izazovi odrazili su se na stanje u lokalnim organizacijama SK i potaknuli rasprave o mnogim do tada prešućivanim i ignoriranim temama iz kojih se očitovala suprotstavljenost reformskih i konzervativnih partijskih grupacija.

Tadanji tajnik Ogranka Matice hrvatske u Gospiću Ante Rukavina ${ }^{16}$ tekstovima „Uvreda i primitivizam“ i „Zapis o ličkim selima - Bužim umire ali se nada" objavljenima u 13. br. Ličkih novina izazvao je brojne javne polemike i reakcije partijskih i kasnije pravosudnih institucija. U rubrici Pisma čitalaca objavljeno je njegovo pismo datirano s 21. 6. 1971. u kojemu je pisao o uvredi nanesenoj hrvatskoj himni na završnoj svečanosti Osnovne škole Nada Dimić održanoj 12.6. 1971. Tada je, prema napisanom, na početku svečanosti učenički glazbeni zbor izveo najprije jugoslavensku himnu Hej Slaveni ${ }^{17}$ koju su svi nazočni slušali s poštovanjem, stojeći, a kad je nakon nje izvođena Lijepa naša ${ }^{18}$ nastavnici

15 Zašto neki napuštaju Savez komunista, Ličke novine, br. 13, 1. 7. 1971.

16 Ante Rukavina (Gospić, 4. 10. 1928. - Gospić, 29. 1. 1994.), veterinar, književnik i publicist. Osnovnu školu i gimnaziju završio je u Gospiću, Veterinarski fakultet u Zagrebu na kojemu je doktorirao 1984. Bio je član Društva hrvatskih književnika, član planinarskih organizacija i institucija, član glavnog odbora Planinarskog saveza Hrvatske, uredničkog vijeća Naših planina. Odlikovan je posmrtno Redom Danice hrvatske s likom Marka Marulića za kulturu i Redom Danice hrvatske s likom Franje Bućana. Jedan je od osnivača ogranka Matice hrvatske u Gospiću početkom hrvatskog proljeća i predsjednik njezina ogranka obnovljenog 1990. Svojim člancima i knjigama uvrstio se među najčitanije i najbolje planinarske pisce. Ana TomLJEnović, Rukavina, Ante, Leksikon Ličana, ur. Ivica Mataija, Gospić, 2017., 251 - 253.

17 Svečana pjesma Hej Slaveni prvi je put kao neslužbena jugoslavenska himna izvedena na I. zajedanju AVNOJ-a 1942. u Bihaću. Izvorno je riječ o himničnoj pjesmi slovačkog pjesnika Samuela Tomašika Hej, Slovaci, napisanoj 1834. Pjesma se brzo proširila po cijelom slavenskom prostoru, a u Hrvatskoj je prvi put objavljena u Danici ilirskoj 1837. na slovačkom i u hrvatskom prijevodu. Na hrvatski ju je prepjevao Dragutin Rakovac 1838. po nazivom Dub Slavjinski, a kasnije je objavljivana s naslovima Duh Slavjanski, Duh Hrvatski, Oj Iliri, Oj, Hrvati. Kao neslužbena himna druge Jugoslavije prvi je put izvedena na Ustavotvornoj skupštini 29. 11. 1945. u Beogradu. Iako su jugoslavenske komunističke vlasti od samoga početka tragale za prikladnijom himnom, i u tom smislu raspisale više javnih natječaja, himna Hej Slaveni zadržala se kao najprihvaćenija iako je službenom himnom SFRJ postala tek 1988. Usp. Tomislav Kučınić, Himne na tlu Hrvatske u 20. stoljeću, diplomski rad, Zagreb, 2019. U kontekstu hrvatskoga proljeća himna je simbolizirala politički unitarizam i otpor hrvatskim reformacijskim procesima.

18 Pjesma Horvatska domovina Antuna Mihanovića objavljena je u desetom broju književnog lista Danica 1835., a uglazbio ju je Josip Runjanin 1848., kad je postala jedna od najpopularnijih hrvatskih popijevki. Popijevka se pod nazivom Lijepa naša domovino prvi put spominje tek 1864., a krajem stoljeća taj je naslov u potpunosti zamijenio originalni naziv pjesme Antuna Mihanovića. Tijekom 19. stoljeća Lijepa naša pjevala se u svečanim prilikama kao jedna od mnogih narodnih himni, a prvi je put kao hrvatska himna izvedena prigodom izložbe Hrvatsko-slavonskog gospodarskog društva u Zagrebu 1891. Kao neslužbena hrvatska himna izvodila se u svečanim prilikama prije, između, ali 
su učenicima naredili da sjednu, što su većina učenika i gotovo svi nastavnici i učinili. „Ta nečuvena uvreda sigurno je jedinstven slučaj omalovažavanja i hrvatske državnosti, a ostat će u sjećanju prisutnih kao teška trauma, naročito djece za koju je sigurno da će himnu ubuduće češće čuti, ali i slušati stojeći. A nastavnici na taj način što nisu odali poštovanje hrvatskoj himni »zahvaljuju« narodu koji je stvorio himnu i Republiku u kojoj žive za povjerenje što mogu obrazovati njezine najmlađe generacije. "19 U tekstu o Bužimu pisao je o smještaju, povijesti i tužnoj onodobnoj stvarnosti u kojoj je selo, bez struje, vodovoda i uređene ceste prema Gospiću, svakodnevno umiralo. ${ }^{20} \mathrm{Na}$ kraju članka, u ime Bužimaca, obratio se općinskim funkcionerima, i prvom među njima, riječima: „I poručuju ti druže Mićo Jelača, predsjedniče općine da ih ne zaboraviš kao do sada, jer Bužim neće umrijeti, osim ako nije tako naređeno.“21 No, pravu je reakciju izazvao dio teksta koji se odnosi na stanje u bužimskoj školi u kojoj u to vrijeme ni jedan nastavnik nije bio iz samog sela „nego su čak i druge vjere, pa usput primjećuju da se na njihovoj školi rijetko kada može vidjeti hrvatska zastava“. ${ }^{22} \mathrm{Na}$ navedeni je tekst koji se odnosi na učitelje u Bužimu reagirao nastavnik Mićo Dragaš koji je upozorio da „pristup problematici je ne samo totalno laički nego i antimarksistički i suprotan platformi djelovanja Saveza komunista Jugoslavije (... “. ${ }^{23}$ Najviše ga je više zabrinuo dio teksta koji govori o nacionalnoj pripadnosti bužimskih učitelja ističući: „Čini mi se da ovakvi stavovi nemaju ništa zajedničkog sa stanovništvom Bužima, a ako je istina da su ovo njihovi stavovi, a kao njihove nudi nam ih pisac članka, nešto tamo nije u redu. $U$ svakom slučaju preporučio bih stanovništvu Bužima, da sapere ovu ljagu sa sebe i da se ograde od ovih postavki. “24 Dragaš naglašava nespojivost teza iz teksta s političkim i ideološkim ambijentom tadanjeg Gospića, no još ga više čudi „kako se smije tako nešto pojaviti na stupcima novina (...) ovdje netko mora odgovarati.

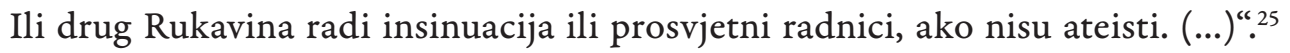

i nakon dva svjetska rata. Službeni status dobila je 29. veljače 1972. ustavnim amandmanom prema kojem je proglašena službenom himnom Socijalističke Republike Hrvatske. Ustavom Republike Hrvatske iz 1990. pjesma je dobila status himne samostalne Hrvatske, a njezin tekst i notni zapis utvrđeni su Zakonom o grbu, zastavi i himni. (https://www.sabor.hr/hr/o-saboru/povijestsaborovanja/zanimljivosti/lijepa-nasa-domovino-put-od-stotinu-godina-do-statusa), posjećeno 19. 5. 2020.

19 Uvreda i primitivizam, Ličke novine, br. 13., 1.7. 1971.

20 U Bužimu se 24. 3. 1912. rodio i Jakov Blažević.

21 Bužim umire - ali se nada, Ličke novine, br. 13., 1.7. 1971.

22 Bužim umire, Ličke novine, br. 13., 1. 7. 1971.

23 Bužim umire, ali se nada, Ličke novine, br. 15 - 16., 1. - 15. 8. 1971.

24 Bužim umire, Ličke novine, br. 15 - 16., 1. - 15. 8. 1971.

25 Bužim umire, Ličke novine, br. 15 - 16., 1. - 15. 8. 1971. 
Bužimska je tema nastavljena i u 19. br. Ličkih novina u kojem je prije teksta stanovnika Bužima kojim oni osporavaju teze Miće Dragaša, kao uvodnik objavljeno Pismo izvršnog odbora SSRN-a u kojem stoji da je SSRN, nakon što je dobio navedeno pismo organizirao sastanak sa stanovnicima Bužima kako bi se uvjerio u njegovu istinitost i na proširenoj sjednici OK SSRNH zaključio da je zahtjev Bužimaca da se pismo objavi u Ličkim novinama opravdan te da se pismo objavi u sljedećem broju. U navedenom pismu Bužimci, odgovarajući na Dragašev tekst, upozoravaju na izostanak hrvatskih zastava prilikom državnih praznika i nazočnost samo srpskih i jugoslavenskih, na namjerno slanje na ponavljanje razreda $30 \%$ učenika škole uz navodnu opasku učitelja: „Ove godine priklati ih, a dogodine sasvim. A što je taj nastavnik kod nas tako izrazio i on je Srbin, onda tome mi nismo krivi. “26 Navode također da ni jedan učitelj škole nije završio pedagošku akademiju, a da dva domaća stanovnika imaju završenu školu, ali su nezaposleni. Na kraju kritiziraju Dragašev tekst i daju potporu pisanju Ante Rukavine koje će se 1972. naći na dnevnom redu Općinskog komiteta Saveza komunista Hrvatske pri obračunu s nacionalizmom.

Unitaristi su svoje stavove i demonstraciju moći javno pokazali na obilježavanju 30. godišnjice ustanka, 27. 7. 1971., na mitingu u Srbu. Na proslavi su sudjelovali Vladimir Bakarić, Savka Dabčević Kučar, Miko Tripalo, Veljko Milatović, Dragoslav Draža Marković, ${ }^{27}$ Đoko Jovanić, narodni heroji i predstavnici JNA. Ličke su novine u br. 15 - 16 donijele poseban prilog na četiri stranice $s$ govorima Ice Đukića, ${ }^{28}$ Đoke Jovanića i Vladimira Bakarića. „Na velikom narodnom zboru u Srbu, na centralnoj proslavi Dana ustanka naroda Hrvatske, govorio je dr. Vladimir Bakarić. Pozdravljen oduševljenim pljeskom ${ }^{29}$ i često prekidan izrazima odobravanja, dr. Bakarić je rekao: „(...) treba još naglasiti (...) ulogu Srba u narodnooslobodilačkoj borbi Hrvatske. Jedna takva statistika poslije rata, od onih preživjelih prebrojanih boraca (...) pokazuje da su Srbi dali otprilike trećinu Narodnooslobodilačke vojske u Hrvatskoj. (...) Ovo nije suha brojka. Ona pokazuje koliko su Srbi vezani za ovu zemlju i koliko prava u njoj imaju da traže njen daljnji razvoj, da tom razvoju doprinesu i da sami u

26 Bužimci o Bužimu, Ličke novine, br. 19., 1. 10. 1971.

27 Dragoslav Draža Marković bio je predsjednik Skupštine SR Srbije, predvodnik tadanjih konzervativnih, velikosrpskih grupacija u vojsci, policiji i državnoj i republičkoj administraciji, protivnik reformskih procesa u SFRJ, ali i u onih u SR Srbiji.

28 Ico Đukić (Oravac, 1933.), dipl. pravnik, bio je predsjednik SO Donji Lapac.

29 Autor reportaže iz Srba je u transkripciji govora Vladimira Bakarića u tekstu posebno u zagradama naznačio trenutak kad su okupljeni njegov govor prekidali pljeskom. To se tijekom govora dogodilo sedam puta, a na kraju je govora autor reportaže zapisao: Dugotrajni pljesak. 
njemu sudjeluju. (Pljesak).“30 Među ostalim, pohvalio je i čišćenje zagrebačke organizacije SK od nacionalista i najavio nastavak pročišćavanja svih organizacija SK, SSRN, SUBNOR-a i drugih. Savka Dabčević Kučar tu je proslavu opisala kao svesrpsku. ${ }^{31}$

Ljeto 1971. obilježile su i studentske aktivnosti, njihov zagrebački plenum i reakcije na njega. Međuopćinska konferencija SK za Liku i predsjednici pet općinskih ličkih konferencija osudili su stavove studentskog plenuma, potporu koju su im dali studenti Splita i Zadra te iskazali punu potporu politici Centralnog komiteta SKH najavivši veći angažman po tom pitanju poglavito u Gospiću, jedinom ličkom studentskom gradu. Na tragu tih stavova, u Gospiću je 31. 8. 1971. održan skup omladine i studenata ${ }^{32}$ na kojem su usvojeni, na „tekovinama NOB i Socijalističke revolucije, bratstva i jedinstva“ utemeljeni, oštri Zaključci o osudi i odbacivanju Saopćenja Predsjedništva Saveza studenata Hrvatske kao i djelatnosti pojedinih studentskih predstavnika, koji su kvalificirani kao antikomunistički, antisamoupravni i nacionalistički te označeni kao politička diverzija. U zaključcima se tražila odgovornost vodstva Saveza studenata Hrvatske, ali i od organa Općine Gospić OK SK da budu „efikasniji i dosljedniji u razračunavanju sa svim neprijateljima (... “33 te dana potpora

30 Dr. Vladimir BAKARIĆ, Revolucija koju smo počeli prije 30 godina traje i danas, Ličke novine, br. 15 - 16, 1. i 15. 8., 1971.

31 „Bez našega znanja (...) nekoliko su desetaka autobusa dovezli na taj dan Srbe iz Bosne, Vojvodine, i iz uže Srbije. (...) Oni su, a ne toliko domaće srpsko stanovništvo, dali velikosrpski pečat toj hrvatskoj proslavi. (...) Nikada, u cijelom svom sudjelovanju na mnogobrojnim sastancima, mitinzima, proslavama, nisam doživjela nešto slično. (...) Bio je vedar, sunčan dan. Kad smo se pojavili na improviziranoj pozornici, na otvorenom, pred golemim mnoštvom ljudi (dovezenih), osjetili smo prema sebi zid otpora i mržnje. To je bio miting velikosrpske bodlje mržnje prema hrvatstvu i Hrvatskoj. Nikako ga drukčije ne mogu shvatiti. Ovacijama su dočekali srbijanske predstavnike, posebice Dražu Markovića za kojeg se znalo da je protiv naše politike. Ovacije su priredili i Đoki Jovaniću, svojemu ratnom zapovjedniku. Hrvatskim predstavnicima (i govornicima) nisu pljeskali, jedva uljudno, čak ni Vladimiru Bakariću ni Jakovu Blaževiću. Ta manifestacija bila je dobro organizirana sa željom da nam se pokaže njihova snaga; a poruka je bila: Velikosrpstvo je tu, iza nas! (...) Jesam li to u svojoj zemlji, gdje li se to nalazim?" Savka DABČEvić KuČAR, '71.: hrvatski snovi i stvarnost, Zagreb, 1997., 337 - 339. O proslavi je Tripalo napisao: „Ljeto je proteklo relativno mirno, izuzimajući polemiku s Bakarićem oko države te neugodnu atmosferu na proslavi ustanka u Srbu. Uz Đoku Jovanića, što je razumljivo i opravdano, najviše je aplauza dobio Draža Marković, što je pokazivalo da nije bez rezultata ostala uporna klevetnička kampanja o ugroženosti Srba u Hrvatskoj, posebno kod boraca Ličana, koloniziranih u Vojvodini, koji su prisustvovali ovoj proslavi u velikom broju.“ Miko Tripalo, Hrvatsko proljeće, Zagreb, 1989., 159.

32 Riječ je o proširenoj sjednici Predsjedništva Općinske konferencije Saveza omladine Gospić na kojoj su sudjelovali članovi predsjedništva Saveza omladine Gimnazije „Nikola Tesla“, tvornice „Marko Orešković“, „Meting“, Šumskog gospodarstva, omladine Ličkog Novog, Odbora Saveza studenata Pedagoške akademije i gospićki studenti koji su studirali u drugim sveučilišnim gradovima.

33 Zaključci, Ličke novine, br. 18., 15.9. 1971. 
politici Josipa Broza Tita, Saveza komunista Jugoslavije i Centralnog komitete SKH, osobno Vladimiru Bakariću, Jakovu Blaževiću i Savki Dabčević Kučar. ${ }^{34}$ Reakcija gospićke omladine uslijedila je nakon Tripalova govora na Hvaru 22. 8. 1971. u kojemu je kritizirao Savez studenata Hrvatske i Savez studenata Zagreba nakon njihove izjave od 14. 7. 1971. u kojoj su zahtijevali beskompromisna rješenja i obračun s centralizmom, separatizmom i unitarizmom, političke smjene, promjenu politike raspolaganja devizama, podržavali Tita i predlagali promjenu imena Jugoslavije. „Osuda programskih smjernica Saveza studenata Hrvatske i Zagreba jasno daje do znanja da CK SKH nije u toj fazi bio za liberalizaciju političkog života ili radikalniju demokratizaciju. (...) U toj fazi 'borbe za Hrvatsku' studentski nastupi i radikalniji sukob za SK nije bila politički poželjna. “35 Svojevrsni nastavak obilježavanja Dana ustanka uslijedio je od 2. do 9. 10. 1971. „općenarodnom vojno-političkom manifestacijom“,

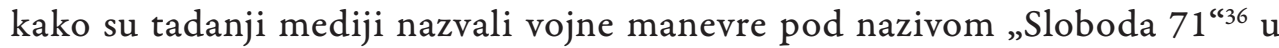
kojima su osim JNA sudjelovale Teritorijalna obrana i Civilna zaštita. Vježba je dijelom održana i na području Like, a nazočio joj je i Josip Broz Tito čije su stavove i političke procjene hrvatski političari cijele 1971. vrlo pomno pratili/slušali i analizirali, svjesni da će o njegovim dojmovima o zbivanjima u Hrvatskoj ovisiti i njihova politička sudbina, ali i sudbina procesa kojima su nastojali upravljati. ${ }^{37}$ Tito se tijekom vojne vježbe zanimao i za prilike u Lici, posebno u svjetlu informacija o međunacionalnim sukobima koje su mu

34 Takva formulacija i odabir imena istaknutih članova SK svakako nije slučajna i govori u prilog stavu gospićkih komunista koji su svjesni podjela unutar CK SKH i na taj način pokazali svoju očitu privrženost njegovu konzervativnom dijelu, ostavljajući potporom Savki Dabčević Kučar ipak otvorenom mogućnost političkog preživljavanja u još uvijek sasvim neizvjesnom ishodu političkih procesa unutar hrvatskog SK.

35 D. Dukovs KI, Istra i Rijeka u Hrvatskome proljeću, 253 - 254.

36 Bila je to jedna od najvećih vojnih vježbi u poratnoj Europi na kojoj je sudjelovalo 40000 pripadnika JNA i TO s 580 tenkova i 850 padobranaca. Vježba je izvedena na širem prostoru omeđenom rijekama Unom, Savom, Krkom i masivima Velike i Male Kapele te Plješivice, a obuhvaćao je Žumberak, Belu krajinu, Pokuplje, Baniju, Kordun, Cazinsku krajinu i dio Like. Većina borbenih djelovanja odvijala se na prostoru Petrova gora - Jastrebarsko - Metlika - Črnomelj - Ogulin Plaški - Tržac - Velika Kladuša.

37 O promjenjivom odnosu Tita prema hrvatskom političkom vodstvu tijekom 1971. svjedoči i Tripalo. „Imali smo njegovu podršku do sredine 1971, ne zato što smo bili političko rukovodstvo Hrvatske, nego zbog toga što je bio suglasan s osnovnim stavovima politike koju je SKH zastupao. Otpor našoj politici objektivno je bio uvjetovan trenutno suprotnim interesima drugih republika, a subjektivno ugroženošću vladajuće pozicije birokracije. Realno gledajući naša je politika pala, jer smo »preuranili«, bili smo u manjini u jugoslavenskom rukovodstvu." M. Tripalo, Hrvatsko proljeće, 11. „(...) Titu je odgovarao hrvatski otpor srpskome unitarizmu i centralizmu, te je on, čini se preko Vladimira Bakarića, inicirao 10. sjednicu CK SKH (...) ali od nje nije očekivao ništa više do kritike unitarizma i centralizma." D. Du Kovs KI, Istra i Rijeka u Hrvatskome proljeću, 40. 
tendenciozno, i u pismima upućenima Jovanki Broz, prezentirali predstavnici konzervativnog dijela Saveza komunista. U govoru održanom tijekom vježbi rekao je: „Ja sam bio u Lici na Plitvicama. Tamo su bili i neki rukovodioci. Pitao sam što to radite, što je to kod vas, kakve vi to straže morate držati oko srpskih sela, tko bi to sada napadao, tko je taj ? ${ }^{38} \mathrm{Kažu}$, to nije istina. To su čista srpska sela, što nama trebaju straže? Pa mi imamo većinu ovdje, kad bi se baš o tome radilo. Nema tu toga, kažu, nego su to počeli da pronose neki izvana. Sada, međutim, treba raditi i pronaći izvore toga - tko su ti ljudi koji unose taj nemir.“" ${ }^{39}$ Očito je, osim testiranja sustava ONO i DSZ, vježba poslužila za propitivanje stanja na hrvatskom, u nacionalnom smislu vrlo osjetljivom području, ali i za discipliniranje i zastrašivanje hrvatskih reformista koji su s vježbi ipak otišli relativno mirni.

OK SKH Gospić usvojio je 19. 10. 1971. god. Zaključke ${ }^{40}$ sa 17 točaka koji su predstavljali svojevrsni poziv za mobilizaciju članstva i najavu političkih i pravosudnih obračuna s neistomišljenicima. Tekst Zaključaka u cijelosti je prožet duhom borbe protiv nacionalista i šovinista, inforbiroovskih pokušaja i pokušaja svih ostalih neprijatelja „da unesu zabunu kod stanovništva naše komune“, posebno pri razmatranju ustavnih amandmana, u čemu su na dodatni angažman pozvali članove Saveza omladine i boraca. Posebno se Općinski komitet koncentrirao na rad lokalnih sredstava informiranja (Ličke novine i Radiostanica Gospić) tražeći da javnost što realnije informiraju. U 4. se točki od svih ogranaka Saveza komunista tražila analiza s posebnim naglaskom na pojave nacionalizma i šovinizma koju je Komitetu trebalo dostaviti do 10. 11. 1971. te stegovno postupanje prema članovima Saveza komunista za koje se procijeni da su djelovali u tom duhu. Od komunista se također tražilo da takve prijavljuju Komitetu i nadležnim organima sudova, tužilaštva i unutarnjih poslova. Komitet je u 5. točki vrlo otvoreno disciplinirao i zaposlenike sudova, odvjetništva i policije tražeći snažniji angažman u primjeni represivnih mjera prema izgrednicima. U 7. se točki naglašava da će Općinski komitet i organizacije Saveza komunista idejno i politički usmjeravati rad pododbora Prosvjete i Ogranka Matice hrvatske kako one ne bi postale antisocijalističke organizacije.

38 O ugroženosti Srba u Lici Tito je govorio Tripalu i u Beogradu 15. 6. 1971. prigodom sastanka Izvršnog komiteta Predsjedništva SKJ. „Tito je rekao da je u Hrvatskoj problem srpska manjina u Lici i u drugim dijelovima republike, a njih se ne može ignorirati. Tripalo je odgovorio da $u$ Hrvatskoj nisu problem Srbi, nego da probleme u Hrvatskoj imaju Hrvati.“ Jasper RIDLEY, Tito Biografija, Zagreb, 2000., 432.

39 M. Tripalo, Hrvatsko proljeće, 162.

40 Zaključci su objavljeni u Ličkim novinama, br. 22 i 23, 15. i 29. 11. 1971. 
Savka Dabčević Kučar posjetila je Gospić 27. 10. 1971. i sastala se s političkim aktivom Like. Budimir Korica tom je prigodom u svom izlaganju naznačio i probleme unutar samog Saveza komunista koji se odnose na reforme i amandmane na Ustav koji se ogledaju u stavovima pojedinih članova Saveza komunista koji su smatrali da će reformski kurs partije dovesti do raspada Jugoslavije. „Ovi »kritičari« vide šovinizam u svemu, da oni pišu pisma čak drugu Titu kako je u Lici narasla šovinistička histerija do te mjere da su Srbi zaplašeni, da čuvaju straže oko svojih sela i domova, da je rukovodstvo SKH u najmanju ruku tolerantno prema pojavama te histerije i sl. (...) Tako oni »informiraju« druge o nama, a isto tako pokušavaju informirati nas o drugima. “41 Korica je i na 22. sjednici CK SKH, održanoj 5. 11. 1971., podržao izlaganje Savke Dabčević Kučar odbacivši tezu o ugroženosti Srba i konstruirane dojmove „»kako u Lici Srbi spavaju pod oružjem i pištoljima pod jastucima ...« izmišljotine su, a takvo je ...»pričanje o situaciji u Lici nepošteno i u najmanju ruku uvredljivo« Ličani ne žele o tome razgovarati, nego o gospodarskom napretku Like.“42

$\mathrm{Na}$ temelju depeše zamjenika sekretara Izvršnog komiteta Centralnog komiteta SKH Dušana Dragosavca, od 3. 12. 1971., Općinski komitet Gospić organizirao je danonoćno dežurstvo u zgradi komiteta i mnogim gospićkim poduzećima i ustanovama. Iz depeše je razvidno da je dežurstvo organizirano kao svojevrsna priprava 23. sjednice Centralnog komiteta SKH u svjetlu očekivanih materijala „predsjedništva SKJ i sjednice u Karađorđevu“. Ličke su novine u 24. br., 15. 12. 1971., nakon poznate 21. sjednice Predsjedništva CK SKJ u Karađorđevu, ${ }^{43}$ na naslovnoj stranici objavile naslove tekstova Odlučno

41 Budimir Korica, Pred nama je razdoblje kada se moramo punom snagom okrenuti rješavanju problema razvitka ovog kraja, Ličke novine, br. 21, 1. 11. 1971.

42 Savka DABČEvić KUČAR, '71.: hrvatski snovi i stvarnost, Zagreb, 1997., 691.

43 Josip Broz Tito je u svom omiljenom lovištu Karađorđevu 30. 11. i 1. 12. organizirao sastanak $s$ hrvatskim političkim vodstvom, koji je prema sjećanju sudionika trajao 20 sati i na njemu se razgovaralo o političkoj situaciji i neslaganjima u hrvatskom rukovodstvu. [„Rascjep u hrvatskom rukovodstvu koje se naziralo već na Četvrtoj konferenciji SKH (srpanj 1971.), posebno je došao do izražaja na 22. sjednici CK SKH. Na toj sjednici održanoj 5. i 6. studenog 1971. pročitana su dva referata, koji su ustvari predstavljali 'političke programe' suprotstavljenih 'frakcija' u hrvatskom rukovodstvu. Jedan, 'službeni', pročitala je predsjednica CK SKH Savka Dabčević-Kučar, a drugi član IK CK SKH Dušan Dragosavac. Unatoč tome, više snaga još uvijek je bilo na strani 'proljećara', pa je referat predsjednice CK SKH prihvaćen 'kao obavezni partijski dokument i osnova za buduću aktivnost SK. "Hrvoje KLAsić, Hrvatsko proljeće u Sisku, Zagreb, 2006., 167.] Od 19 hrvatskih predstavnika jedanaestero njih nije se slagalo s Titovim procjenama stanja u Hrvatskoj. Sastanak je završio bez oblikovanog zaključka i bez odluke hoće li o stanju u Hrvatskoj raspravljati Predsjedništvo CK SKJ. Sjednica Predsjedništva, kojoj je Tito promijenio dnevni red, pa se umjesto o idejno-političkim osnovama novog petogodišnjeg plana raspravljao 
protiv neprijatelja socijalizma, Tito: Savez komunista je jedini faktor koji ima pravo djelovanja u općejugoslavenskim okvirima i Svatko u svojoj sredini treba povesti odlučnu akciju protiv antisocijalističkih pojava u kojima je na više stranica prenesen završni govor Josipa Broza i zaključci Predsjedništva. U istom su broju na 5. str. objavile nekoliko pisama i brzojava domaćih partijskih struktura upućenih uglavnom Titu i Predsjedništvu SKJ-u. U njima, na temelju analiza sa sastanaka održanih 8. 12. 1971., daju podršku Titovim izlaganjima prisežući na beskompromisnu borbu protiv neprijatelja. Tim su nastojanjem intonirani i brzojavi upućeni CK SKH. Svim je brzojavima i pismima bilo zajedničko traženje i najava obračuna s neprijateljima unutar lokalne zajednice. Ličke su novine tek na pretposljednjoj stranici toga broja donijele kratku vijest s 23. sjednice CK SKH o ostavkama vodstva CK SKH.

Hrvatsko je proljeće na gospićko područje donijelo intenzivna politička previranja označena težnjom dijela gospićke javnosti za afirmacijom hrvatskog političkog, kulturnog i jezičnog identiteta. U tom su se ambijentu i pitanja statusa hrvatskog jezika, posebno u javnoj i službenoj uporabi te u obrazovnom sustavu, prenijela iz stručnih i znanstvenih krugova u sferu dnevne politike i privatne polemike. Pitanje jezika postalo je važno političko i identitetsko pitanje, a inzistiranje na položaju i osobitostima hrvatskog jezika redovito je u partijskim strukturama stigmatizirano kao nacionalističko i šovinističko, ono koje ruši doktrinu bratstva i jedinstva te tekovine NOR-a. Općinski se komitet SK u Gospiću pitanjima jezika bavio već početkom 1970-ih. Povod nacionalizmu na širem gospićkom području pronalazili su i u jeziku medija, posebno negativno ocjenjujući tadanju Televiziju Zagreb za koju su, poglavito 1971. i 1972., držali da izrazito vidljivo manipulira jezikom.

o političkoj situaciji u Hrvatskoj, održana je 2. 12. 1971. Nakon Titova uvodnog govora, sudionici sastanka, najviši politički rukovodioci iz cijele Jugoslavije su, po ranije pripremljenim obrascima kritizirali hrvatsko vodstvo. $S$ tog sastanka potječe za komunistički politički poredak paradigmatska Titova rečenica upućena sudcima: „često se drže paragrafa kao 'pijan plota'. I onda obrću taj paragraf na sve strane, nalazeći uvijek ono što krivca oslobađa, a ne gledaju na ono suprotno socijalističkom razvitku." D. Dukovski, Istra i Rijeka u Hrvatskome proljeću, 304. Usprkos kritičnosti sjednice u Karađorđevu, njezine su se posljedice na političke prilike u Hrvatskoj drastično odrazile tek nakon 23. sjednice CK SKH, 12. i 13. prosinca 1971., kad su osobno ostavke podnijeli Savka Dabčević Kučar, Perko Pirker, Marko Koprtla i Janko Bobetko, a pročitana je ostavka Mike Tripala na članstvo u Izvršnom komitetu Centralnog komiteta SKJ i Predsjedništvu SFRJ. Osim navedenih, ostavke su podnijeli brojni politički dužnosnici na različitim razinama, javni i novinski djelatnici, urednici i direktori novinskih kuća. 


\section{POSLJEDICE DRUŠTVENIH I POLITIČKIH PREVIRANJA U OKVIRU HRVATSKOG PROLJEĆA U GOSPIĆU}

Ličke političke prilike nakon Karađorđeva i 23. sjednice Centralnog komiteta SKH ilustrira i Informacija Općinskog komiteta SK Gračac upućena 14. 12. 1971. Centralnom komitetu SKH u kojoj se ističe da na području Gračaca nije bilo pojava organiziranih neprijateljskih snaga, ali se osjećala atmosfera uznemirenosti i iščekivanja i da je od Međuopćinskog komiteta Gospić zatraženo da se na sljedećoj sjednici razmotri aktivnost Budimira Korice, odnosno njegova odgovornost za slabu komunikaciju s organizacijama Općine Gračac i nevjerodostojnog interpretiranja gospodarske situacije u Općini. Bio je to očito povod raspravama općinskih komiteta o povjerenju Budimiru Korici koje su nastavljene na Plitvicama 21. 12. 1971. gdje je održana proširena sjednica Predsjedništva Međuopćinskog komiteta za Liku na kojoj su bili nazočni Jakov Blažević, Dušan Dragosavac, Milan Kuprešanin ${ }^{44}$ i Milan Majstorovićc ${ }^{45}$. Predsjedništvo je procijenilo da je politička situacija u Lici prije i nakon Karađorđeva povoljna, da su „Usamljeni slučajevi šovinizma u proteklom periodu na vrijeme suzbijeni. Inače u Lici (...) nije bilo ni jednog ekscesa ili »slučaja « koji bi zavrijedio pažnju javnosti. “46 No, pojavio se u to vrijeme, posebno na područjima $s$ većinskim srpskim stanovništvom, duh revanšizma na koje je u raspravi posebno ukazao predsjednik Općinskog komiteta SK T. Korenica. Sekretar Općinskog komiteta SKH Gospić Petar Kuprešanin ukazao je na slabu suradnju između općinskog i međuopćinskog komiteta, a o političkoj odgovornosti Budimira Korice govorio je predsjednik Općinskog komiteta SKH T. Korenica Nikola Lapov koji je „rekao da je Općinski komitet u Titovoj Korenici prenaglio kad je otvorio raspravu o tome bez njegova prisustva. (....).“ On je tu sjednicu nazvao političkom avanturom koja je podijelila Komitet i stanovništvo. Formalno su Koricu optužili da na sjednicama Centralnog komiteta SKH nije prezentirao gospodarske prilike u Lici, no usprkos tomu zaključili su da je traženje njegove političke odgovornosti bio brzoplet potez i iskazali mu povjerenje. $U$ javnom su diskursu, poglavito tijekom siječnja, dominirali brzojavi podrške i novih prisega Titu i njegovu uvodnom i završnom govoru u Karađorđevu, koje su slale i javno publicirale udruge rezervnih starješina, SUBNOR, omladina i studenti Gospića, SSRN Gospić. U istom je broju Ličkih novina Općinski komitet Gospić (str. 10 - 11) objavio Program akcija Općinske organizacije SK u kojemu je kroz 19 točaka javnosti objavljen

\footnotetext{
44 General-pukovnik Milan Kuprešanin bio je predsjednik Republičkog odbora rezervnih starješina.

45 Milan Majstorović bio je član Republičke konferencije SSRN Hrvatske.

46 Tito nam je pomogao da tražimo krivce na pravom mjestu, Ličke novine, br. 1, 1. 1. 1972.
} 
popis aktivnosti i rokovi njihovih izvršenja koji su proistekli iz Karađorđeva, a koji se uglavnom odnose na obračun s nacionalizmom i šovinizmom. Aktivnosti su, osim na sam SK i njegova tijela i članove, bile usmjerene na rad pravosudnih tijela, organa unutarnjih poslova, lokalnih medija, ${ }^{47}$ pododbora Prosvjete u Metku i Matice hrvatske u Gospiću. Rok u kojemu je Komitet trebao raspravljati o Matici određen je s 25. 12. 1971. U Ličkim je novinama objavljen članak ${ }^{48}$ u kojemu su doneseni zaključci s Općinskog komiteta SK Gospić koja je, među ostalim, trebala rasformirati Ogranak Matice Hrvatske u Gospiću i Pododbor Prosvjete u Metku. Na Izvršnom odboru Općinskog komiteta SSRNH, 24. 1. 1972., posljednjem u tadanjem sazivu, uz nazočnost Petra Kuprešanina, sekretara Općinskog komiteta SKH Gospić, i Dane Narančića, predsjednika OK SO Gospić, vodila se rasprava i o plenarnoj sjednici lokalnog SSRN-a od 11. 11. 1971. Tom je prilikom Kuprešanin izrazio neslaganje s ocjenama rada Saveza komunista na području Gospića koju je tada dao Josip Bunčić, predsjednik Općinskog komiteta SSRNH Gospić. Zbog toga je formirana posebna komisija Komiteta sa zadaćom da analizira pojedine diskusije s Plenuma. Na istoj se sjednici, na temelju prijedloga Mjesne organizacije SSRN Medak i nekih drugih organizacija, raspravljalo i o pitanju naziva jezika. „Izvršni odbor je zauzeo stav de se on treba nazvati hrvatskosrpski, pa će se takav prijedlog poslati Ustavnoj komisiji Sabora SRH.“ ${ }^{4}$

Općinska konferencija donijela je na sjednici održanoj 27. 12. 1971. Zaključke u kojima se u 26 točaka inzistiralo na jačanju socijalizma, bratstva i jedinstva, izgradnji suvereniteta SRH uz jačanje jedinstva Jugoslavije, odlučnijoj borbi protiv nacionalizma i šovinizma i obračunu s neprijateljima. Zadužili su sve organizacije da prouče uvodno i završno izlaganje J. B. Tita, provedu diskusije i dostave ih Općinskoj konferenciji koja će tim povodom održati posebnu sjednicu na kojoj će Konferencija ocijeniti „stavove i djelovanje MOK SKH za Liku, stavove i djelovanje članova te Konferencije i djelovanje članova SK s našeg područja u višim organima $S K H$ i SKJ “. ${ }^{\circ 0} \mathrm{U}$ 19. točki Konferencija je donijela i formalnu, jednoglasnu odluku „da se ukine Ogranak Matice hrvatske u Gospiću i Pododbor Prosvjete u Metku jer za takve organizacije na našem području nema razloga da postoje “. ${ }^{51} \mathrm{U}$ tom su duhu Omladina i studenti Gospića, sa zajedničkog

47 Na tom su tragu objavljeni Zaključci OO SK u Ličkim novinama u kojima je, za neprijateljsko djelovanje i istupe protiv naroda i države, javno prozvan njihov djelatnik u riječkoj Radnoj jedinici Ante Maras za kojega su tražili i postupanje nadležnih organa.

48 Velike obaveze pred komunistima, Ličke novine, br. 2., 15. 1. 1972.

49 Tješnja suradnja s omladinom, Ličke novine, br. 3., 1.2. 1972.

so Program, Ličke novine, br. 1., 1.1.1972.

51 Zaključci Općinske konferencije SK povodom 21. Sjednice Predsjedništva SKJ, 27. 12. 1971. (dalje: Zaključci, 1971). 
političkog skupa SO Gospić i Saveza studenata održanog 14. 12., uputili pismo Generalnom komitetu SKH i Predsjedništvu SKJ-u. ${ }^{52}$

Na redovitoj Izbornoj konferenciji SSRNH Gospić, održanoj 4. 2. 1972., za novog je predsjednika izabran Josip Stojević. Međuopćinsko vijeće zajednice ličkih općina i Međuopćinska konferencija SKH za Liku, sa sjednice održane 10. 2. 1972. u Gospiću, Saveznoj su skupštini u Beogradu uputili prijedlog da se J. B. Tito po drugi put proglasi narodnim herojem Jugoslavije. Na sjednici je sudjelovao i Jakov Blažević, a Mićo Jelača ${ }^{53}$ u svom je izlaganju prezentirao i statističke podatke o nacionalizmu na području Like dobivene od Javnog tužilaštva, suda, Centra javne sigurnosti i prekršajnog sudca. Prema tim izvješćima u vrijeme hrvatskog proljeća na području Like zabilježeno je „57 krivičnih prijava sa 74 izvršioca i 138 prekršajnih prijava sa 204 prekršitelja“. ${ }^{54}$ $\mathrm{Na}$ toj su sjednici usvojeni Zaključci u kojima, u 20 točaka, MOK SK za Liku i Međuopćinsko vijeće zajednica ličkih općina prihvaćaju izvješća Službe javne sigurnosti, Općinskog javnog tužilaštva, Okružnog suda u Gospiću i sudaca za prekršaje za područje Like o radu na suzbijanju neprijateljske djelatnosti. Prema njihovoj procjeni te su djelatnosti bile svojstvene uglavnom istupima pojedinaca, a ne organizacija u cjelini. To se posebno odnosilo na Maticu hrvatsku u Gospiću i Pododbor Prosvjete u Metku. „Zbog složenosti situacije na području Općine Gospić što nije karakteristika samo ovog političkog trenutka, već vuče korijen od ranije došlo je kašnjenja u raščišćavanju. " 55 U Zaključcima se poziva i na obračun $s$ „neopravdanih socijalnih razlika bogaćenja (...) menadžerstva, tehnokracije, birokratizma (...) “.56 Očito je iz izvješća da je među članovima SK došlo do međusobnih optuživanja u odnosu na nacionalistička djelovanja i reakcije na njih. Iako se u izvješću ne spominju imena, vjerojatno se dio tih optužbi odnosio na rad Budimira Korice i Josipa Bunčića. Započeti procesi propitivanja djelovanja organizacija i pojedinaca unutar SK nastavljeni su tijekom 1972., a svoje konačno uobličenje doživjeli su tijekom unutarpartijskih izbora u drugoj polovici godine. ${ }^{57}$

$52 \quad S$ tog su skupa usvojeni zaključci s 13 točaka u kojima se traži odgovornost svih onih koji su doprinijeli djelovanju kontrarevolucionarnih snaga, predsjedništva RK SOH, Đure Brodarca, komandanta RŠ OJ, Ivice Vrkića, predsjednika RK SOH, Slavka Meića, člana predsjedništva.

53 Mićo Jelača bio je tada potpredsjednik Vijeća zajednice ličkih općina i predsjednik Skupštine Općine Gospić.

54 Mićo JelaČA, Čuvati bratstvo i jedinstvo, Ličke novine, br. 4., 15. 2. 1972.

55 Zaključci, 1971.

56 Zaključci, 1971.

57 OK SK Gospić započeo je izbornu proceduru u svibnju osnutkom Kadrovske komisije koja je razmatrala pitanje kadrova u SK i Komitetu predložila listu kandidata za dužnosti predsjednika Općinske konferencije SK, sekretara Općinskog komiteta i njihove zamjenike te kandidata za 


\section{U Izvještaju o radu Općinske konferencije SKH i njenih organa u mandatnom} periodu 1970. - 1972. godine $e^{58}$ promatrano je razdoblje opisano kao krizna situacija u SK „gdje je došlo do faktičkog formuliranja »druge političke linije « koja je vodila nacionalizmu pod čijim se pritiskom i ideologijom »masovnog nacionalnog pokreta « odvijala cjelokupna idejno-politička aktivnost općinske organizacije SK. Nastao je mučni period u kom je bilo otežano vođenje jedne ispravne politike i držanje političke situacije u svojim rukama. No, unatoč svim tim poteškoćama Općinska organizacija SKH sačuvana je od prodora kontrarevolucije i organiziranog djelovanja nacionalističkih djelovanja (...) i nije bilo niti jedne pojave frakcionaškog djelovanja, niti podrške stavovima koje su zastupali lideri masovnog nacionalnog pokreta." 59

OK SKH Gospić je 19. 1. 1972. oformio radnu skupinu koja je dobila zadaću da izradi „osnovu za analizu ${ }^{60}$ o eskalaciji nacionalizma na području općine Gospić““61 Tijekom svoga rada, koji je trajao više od mjesec dana, Skupina se konzultirala s javnim tužilaštvom, Centrom javne sigurnosti, Stanicom javne sigurnosti, Službom državne bezbjednosti i prekršajnim sudom čiji su čelnici i neposredno učestvovali u raspravama o političkoj situaciji na području općine zajedno s članovima OK i rukovodstvima društveno-političkih organizacija i Skupštine općine. Skupina je koristila i materijale boračkih organizacija,

predsjednika i sekretara Međuopćinske konferencije SK za Liku. Komisija je održala dvije sjednice i konačno utvrdila prijedlog kandidata koji je razmatran na proširenoj sjednici OK održanoj 6. 6. 1972. na kojoj je, uslijed stava o obaveznoj rotaciji sekretara Komiteta i predsjednika Konferencije kojima je tada protekao dvogodišnji mandat, a imali su po statutu pravo na još jedan, došlo do divergencije mišljenja, pa lista Komisijinih kandidata nije usvojena u cijelosti. Komisija je u svom konačnom prijedlogu predložila za predsjednika Općinske konferencije Željka Centnera, a za zamjenika mu Milana Vujnovića, za sekretara Komiteta Jovu Lazića i Nikolu Petrovića, za predsjednika MOK-a Icu Đukića i Radu Lolića i za sekretara MOK-a Nikicu Ivezića.

58 Riječ je o necjelovito sačuvanom tekstu na 23 stranice u jednoj od ukupno dvije sačuvane arhivske kutije gradiva OK SKH Gospić iz razdoblja 1961. - 1980. u kojoj se nalaze samo sačuvana izvješća o radu i statutarne odluke.

59 HR DAGS-93: Općinski komitet SK Gospić, 1960. - 1987. - Izvještaj o radu Općinske konferencije SKH i njenih organa u mandatnom periodu 1970. - 1972. g., 6.

60 Analiza je nastala u okviru odluke CK SKH na 24. sjednici na kojoj je formirana Komisija sa zadatkom da pripremi izvještaj o stanju u SKH u odnosu na prodor nacionalizma u njegove redove. „Izvještaj komisije razmotren je i usvojen 8. svibnja 1972. godine. Rad na izvještaju odvijao se uporedo i povezano s aktivnošću u organizacijama i rukovodstvima Saveza komunista na terenu, uz njihovu pomoć i suradnju. (...) Prikupljen je golemi činjenični materijal na više tisuća stranica. To su izvještaji, informacije i dokumenti koje su komisije općinskih i međuopćinskih konferencija SKH uputile u Centralni komitet (...).“ (Hrvatsko proljeće. Presuda Partije. Izvještaj o stanju u Savezu komunista Hrvatske u odnosu na prodor nacionalizma u njegove redove, ur. Mirko Mađor, Zagreb, 2003., 9)

61 Analiza, 1972., 1. 
organizacija Socijalističkog saveza i analize 31 područne partijske organizacije koje su ih dostavile $\mathrm{u}$ zadanom roku. ${ }^{62} \mathrm{Na}$ temelju toga rada oblikovana je Analiza političkog stanja na području Općine Gospić u periodu od 1. I. 1971. do 1. III. 1972. g. Riječ je o 59 stranica ukoričenog teksta strukturiranog od uvodnih razmatranja, opisa metodologije rada, sinteze procjene političkih prilika, detaljnog opisa pojedinačnih slučajeva nacionalizma koji očito počivaju na dokumentaciji policijske i obavještajne provenijencije, poglavlja zbirnog pregleda nacionalističkih ispada na području Općine i posljednjem poglavlju, napisanom na 6 stranica, pod naslovom Utvrdivanje stepena političke odgovornosti, koje je posvećeno razmatranju 16 slučajeva nacionalističkog djelovanja u kojemu je svakom od slučajeva određena politička sankcija (izbacivanje iz članstva SK) ili preporučena radno-pravna (onemogućavanje radnog odnosa i onemogućavanje vršenja društvenih i javnih funkcija) ili kaznena sankcija koju su trebali odraditi drugi čimbenici u ovom postupku. Slijed događaja najave iz Analize potvrđen je na razini odluka javnih ustanova i pravosudnih postupaka koji su uslijedili.

U uvodnom dijelu Analize Skupina je procijenila da su na političku situaciju u Općini posebno utjecala sredstva javnog informiranja u razdoblju 1970./71. i ekonomska i politička emigracija te intenzitet veza koje su postojale između nje i obitelji koje su ostale na području Općine. Prema njihovoj procjeni, eskalaciji nacionalizma posebno su doprinijela sredstva javnog informiranja, a posebno tzv. opoziciona štampa (Hrvatski tjednik, HGG ${ }^{63}$, Tlo, Jež64, Studentski list), pa i tekstovi koje su objavljivali Vjesnik, Vjesnik u srijedu, Studio, Feljton i poglavito TV Zagreb. Autori Analize upozoravaju na neravnomjernu medijsku zastupljenost vodećih političara u tadanjoj Hrvatskoj ističući da su Miko Tripalo, Savka Dabčević, Ivan Šibl i drugi u tisku i medijima dobivali nesrazmjerno više prostora od Vladimira Bakarića, Jakova Blaževića ${ }^{65}$ i dr., o

62 Šest organizacija i ogranaka dostavili su samo dokumente, bez ocjene situacije, a sedam partijskih organizacija nisu uopće Komitetu dostavili ocjenu političke situacije.

63 Hrvatski gospodarski glasnik bio je list za gospodarsko-politička pitanja koji su pokrenuli Marko i Vladimir Veselica. Izlazio je, kao polumjesečnik 1971. do br. 14. Nakladnici su bili Društvo ekonomista Hrvatske, kasnije Društvo ekonomista Zagreba, a glavni je urednik bio Vladimir Veselica.

64 Beogradski, protuproljećarski orijentiran, satirični list.

65 Jakova Blaževića u svojoj knjizi Hrvatsko proljeće Miko Tripalo spominje kao nedosljednog političara koji je hrvatske reformiste podržavao sve do sjednice u Karađorđevu, a onda se preobrazio „najprije oprezno, taktički, jer su neki tražili i njegovo uklanjanje, a onda na njemu svojstven grub i bezobrazan način. Tako je nekim zastupnicima Sabora (npr. Kazimiru Zankiu) u svome zanosu tvrdio da ima dokaze da su bivši lideri imali veze s ustaškom emigracijom, da bi na kraju, govoreći o upornosti kontrarevolucionarne linije, povezao Mačeka, Hebranga, Stepinca i smijenjene rukovodioce SKH 1971.“ M. TRIPALO, Hrvatsko proljeće, 193 - 194. 
čijim su nastupima tekstovi skraćivani, neobjavljivani i omalovažavani. U tom su smislu zamjerali Radiostanici Gospić što nije emitirala govor Jakova Blaževića vojnim starješinama na Plitvičkim Jezerima, kao ni govor Milana Kuprešanina na Općinskoj konferenciji SKH Gospić 26. 12. 1971. Iz Radija su se branili da Blaževićev govor nije snimljen jer nisu bili pozvani na taj skup, a Kuprešaninov govor jednostavno nisu snimili. Skupina takav medijski pristup drži odgovornim i za primijećeni „rascjep u CK SKH, koji je bitno utjecao na političku efikasnost organizacije SK naše općine“. ${ }^{66} \mathrm{U}$ analizi medijskog okruženja koji je doveo do euforije nacionalizma posebna je pozornost posvećena tzv. Bužimskom slučaju i polemici koja se oko njega vodila u Ličkim novinama. U Analizi su ti tekstovi posebno tretirani, reagirale su škole u Gospiću i Bužimu, Partija je provela i istragu na temelju koje je zaključila da su posljedice tih članaka, koji po njima ne počivaju na činjenicama nego su plod autorovih nacionalističkih tendencija, dalekosežne i teško procjenjive s obzirom na njihov štetni učinak. „To je vidljivo iz stalne upotreba riječi: »hrvatski, hrvatsku djecu, hrvatske državnosti, hrvatsku himnu «. “67 Autori Analize ističu da su se, usprkos navedenom, Ličke novine i Radiostanica othrvale nasrtajima nositelja ideologije masovnog pokreta. „(...) tako je Radio stanica odbila emitiranje čestitke koju je Ante Rukavina (...) namijenio čitateljima Hrvatskog tjednika ${ }^{68} \gg$ Ličke novine « su se uporno branile od napisa Nikice Valentića koji je omalovažavao revoluciju i učesnike u revoluciji opravdavajući tvrdnje u članku Rabatića koji je izašao povodom podizanja spomenika u Lipama." ${ }^{69} \mathrm{U}$ kategoriju štetnih medijskih utjecaja na političku situaciju na širem gospićkom području Općinski je komitet svrstao i novinske članke objavljene u hrvatskim i srpskim emigrantskim tiskovinama koji su na različite načine, a najčešće u pismima rodbini i prijateljima koje su iz inozemstva slali lički emigranti, stizali na ličko područje. Prema Analizi, organi gonjenja su prema svim oblicima nacionalističkog djelovanja bili dosta tolerantni što je

68 Ante Rukavina je dopisom od 24. 9. 1971. od Radiostanice Gospić tražio da se svakog četvrtka i nedjelje, u razdoblju od 24. 9. do 24. 10. 1971., u okviru programa uputi pozdrav čitateljima Hrvatskog tjednika s pjesmom Tvoja zemlja u interpretaciji Vice Vukova. Taj je njegov zahtjev postao jedna od točaka optužnice koju je protiv njega podiglo Okružno javno tužilaštvo u Gospiću 1972. zbog kriv. djela iz čl. 119. st. $1 \mathrm{KZ}$-a koji glasi: „Ko propagandom ili na drugi način izaziva ili raspaljuje nacionalnu, rasnu ili versku mržnju ili razdor među narodima i narodnostima koje žive u Federativnoj Narodnoj Republici Jugoslaviji, kazniće se strogim zatvorom do petnaest godina." (Službeni list FNRJ, br. 13., 9. 3. 1951., 198) Protiv njega je podignuta optužnica 7. 11. 1972. i odbačena 8. 11. Nakon žalbe Općinskog javnog tužiteljstva 26. 3. 1973., Vrhovni je sud potvrdio oslobađajuću odluku.

69

Analiza, 1972., 5. 
otvorilo dodatni prostor stvaranju političkih prilika u kojima se, po njima, ni SK nije dobro snašao i u tom razdoblju je došlo do „znatnijeg osipanja organizacija SK. Jedan dio članova SK napustio je SK u znak protesta (...).“70

Središnji i najopsežniji dio Analize odnosi se na detaljan opis nacionalističkih događaja na području Karlobaga, Perušića, Studenaca, Pazarišta, Metka, Smiljanskog Polja, Ličkog Osika, Široke Kule, Trnovca, Divosela, Čitluka, Gospića, Jadovnog, PPK Velebita... U njemu su detaljno opisani predmetni događaji, citirani tekstovi pjevanih pjesama i navedena imena osoba koja su u njima sudjelovala. Najviše se takvih događaja zbilo u Perušiću. Očito su kao protutežu hrvatskom autori nastojali opisati i pojave srpskog nacionalizma koji se najčešće odnosio na vrijeđanje Tita, Hrvata i podržavanje Rankovića. U navedenom su poglavlju, osim samih događaja, detaljno opisani i njihovi vinovnici $s$ relativno opširnom političkom, društvenom i radno-pravnom anamnezom koja očito proizlazi iz podataka policijsko-obavještajne provenijencije.

Posebno poglavlje u Analizi posvećeno je radu Ogranka Matice hrvatske u Gospiću $^{71}$ i Pododbora Prosvjete u Metku ${ }^{72}$. O radu Matice i njezinih članova

70 Analiza, 1972., 8.

71 Djelovanje Ogranka Matice hrvatske u Gospiću u predmetnom je razdoblju moguće promatrati na razini dostupnih informacija objavljenih u javnim glasilima, prije svega Ličkim novinama $\mathrm{i}$ podataka iz gradiva OK SKH u Gospiću. Ličke su novine objavile kako je u Gospiću 13. 12. 1970., u organizaciji Matice hrvatske, obilježen 85. rođendan Miroslava Kraljevića. Uz predavanja Ljudevita Jonkea, Matka Peića, Branimira Kempfa i Miroslava Brandta, održanima na Pedagoškoj akademiji, otkrivena je spomen-ploča na mjestu Kraljevićeve rodne kuće i otvorena izložba Kraljevićevih radova koju je Muzej Like organizirao u tadanjem domu JNA. Predstavnici gospićkog Ogranka nazočili su postavljanju spomen-ploče Kraljeviću u Požegi. U Ličkim novinama br. 7 (1. 4. 1971.) objavljen je članak Riječi govore - primjeri pokazuju, posvećen djelovanju Ogranka Matice hrvatske u Gospiću koji je tada brojio 213 članova, od kojih je 25 članova radnika. Ogranak ističe svoju nakladničku djelatnost (objavili su Lički kalendar 1968., zbirku pjesama Zir Zlatka Tomičića, zbirku Tisuću konjanika Ranka Šimića, Kamen Krekovače Jovana Savičina Price i u tisku je knjiga Klicom kletve istog autora. Te su godine planirali tiskati Breme Jure Karakaša i Na dnu sebe Veselka Vidovića), organizirali su javna predavanja i skrbili o kulturnoj baštini (podizanje spomen-ploča zaslužnim ličkim velikanima).

72 Srpsko kulturno društvo Prosvjeta osnovano je 1944. godine u Glini, s osnovnom namjerom da širi prosvjetu i kulturu u redovima srpskog naroda u Hrvatskoj. „(...) Međutim u posljednjem razdoblju njenog djelovanja (...) postepeno dolaze sve jače do izražaja tendencije srpskih nacionalista u Hrvatskoj da to društvo politički zloupotrijebe i iskoriste u svoje nacionalističke ciljeve." (Hrvatsko proljeće. Presuda Partije. Izvještaj o stanju u Savezu komunista Hrvatske u odnosu na prodor nacionalizma u njegove redove, ur. Mirko Mađor, Zagreb, 2003., 237). Iz Prosvjete su intenzivno plasirane teze o ugroženosti Srba u Hrvatskoj, pa slijedom toga i ideje o srpskoj kulturnoj, jezičnoj i znanstvenoj autonomiji u Hrvatskoj. U tom je procesu važno mjesto zauzimala i Srpska pravoslavna crkva. Pododbor Prosvjete u Metku osnovan je 1945. god. s ciljem da na području svoje djelatnosti razvija kulturno-prosvjetne djelatnosti. U svom je sastavu imao folklornu, dramsku, recitatorsku, sportsku i tamburašku sekciju, a u njegov su rad bila uključena 43 člana. Svoje su priredbe 
napisano je ukupno šest stranica teksta, a o radu Prosvjete jedna. Autori Analize opisali su ustroj Ogranka Matice od njezina osnutka, na inicijativu SSRH Općine Gospić, 1966., njezina programska opredjeljenja, broj članova i sustav unutarnjeg biranja te naznačili metodologiju analize usmjerenu na dva motrišta: rad Ogranka kao cjeline i djelovanje njegovih članova koje nije uvijek bilo usuglašeno sa samim Ogrankom. Takav se pristup temeljio na partijskom stavu najviših republičkih tijela SKH da se ne optuži Maticu hrvatsku u cijelosti, već skupinu dužnosnika koje je Matica trebala sama prokazati. „Nakon što Upravni odbor nije pristao na »unutrašnju diferencijaciju u Matici - u noći 11. siječnja 1972. godine otpočeo je udar na Maticu hrvatsku u cjelini. Te noći, sustavno i sinkronizirano, napadnuti su i središnjica i ogranci Matice hrvatske ${ }^{73}$ (...) Te noći, nadalje, policija je počela privoditi i preslušavati dužnosnike Matice hrvatske. ${ }^{\text {"74 }} \mathrm{U}$ tom smislu autori Analize navode da je Ogranak sudjelovao u nekim akcijama Socijalističkog saveza, da je vodstvo Ogranka na poznatom prosvjednom skupu protiv Deklaracije javno osporilo njezina načela, da se također, nakon Karađorđeva, javno ogradio od djelovanja Središnjice Matice i da su se njegovi pojedini članovi osobno ograđivali od „ekstremnih istupa nekih članova Ogranka“. ${ }^{75}$ Silnice udara Analiza je usmjerila na blagajnika Odbora Julija Derossija, ${ }^{76}$ tajnika Antu Rukavinu i člana Ivicu Vukića. Derossi je označen kao jedan od inicijatora osnutka Odbora u Gospiću, podržavatelj Deklaracije, član Zajednice samostalnih pisaca TIN, član uređivačkog odbora Hrvatskog

organizirali u Gospiću, Ribniku, Gračacu, Počitelju, Mogoriću i Vrepcu. „Od svog formiranja do danas Pododbor u svojoj djelatnosti nije zabilježio niti jedan slučaj nacionalističkog i šovinističkog ispada, već je naprotiv njegovo članstvo u cjelini djelovalo na liniji SKJ i u okviru pravilima Pododbora dozvoljenih akcija.“ (Analiza, 1972., 29) Na svojoj posljednjoj skupštini održanoj 6. 1. 1972. god. Pododbor je jednoglasno, na temelju zaključka Općinske konferencije SKH Gospić od 26. 12. 1971. kojom je odlučeno da se pododbor Prosvjete i Ogranak Matice ukinu, usvojio odluku o prestanku rada.

73 Te noći, 11. 1. 1972., i milicijske snage u Gospiću započele su, u 4 sata ujutro, premetačinu stanova istaknutih članova Matice. Usp. Julije Derossı, Čekulade nema - Gospićka ljudikanja, Gospić, 2007.

74 Jozo IvičEvić, Matica hrvatska nakon Karađorđeva, Nepoznata istina o crnom danu za hrvatske domoljube 11. siječnja 1972. - O udaru na Maticu hrvatsku i hrvatsko proljeće - O Hrvatskoj danas, prir. Vlatko Pavletić, Zagreb, 2002., 95 - 96.

75 Analiza, 1972., 24.

76 Julije Derossi (9. 7. 1928. - 28. 11. 2010.); književnik, pedagog i publicist. Od 1964. do 1972. bio je profesor Pedagoške akademije u Gospiću. Zbog političkog progona, nakon pada hrvatskog proljeća, 1972., napustio je Gospić i s obitelji preselio u Zadar gdje je novo zaposlenje dobio tek 1980. u zadarskoj gradskoj knjižnici. Jedan od utemeljitelja pododbora Matice hrvatske u Gospiću. Više godina bio je urednik Ličkog kalendara, urednik i suradnik Hrvatskog književnog lista te redaktor i kolumnist Ličkih novina. (Ivica Mataija, Derossi, Julije, u: Leksikon Ličana, ur. Ivica Mataija, Gospić, 2017., 83 - 84). 
književnog lista, član Odbora Udruženja Hrvatska književna zadruga Svačić koje su razvijale neprijateljsku djelatnost i autor brojnih nacionalističkih članka i osoba koja je „(...) od 1966. godine konstantno u najdirektnijem kontaktu sa nosiocima kontrarevolucionarne aktivnosti u Zagrebu, Zlatkom Tomičićem, Zvonimirom Kolundžićem, Vlatkom Pavletićem i drugim “.77

Ante Rukavina označen je kao idejni pristalica Derossijevih djelovanja i kao osoba koja je u tisku raspirivala nacionalnu mržnju i netrpeljivost. Analiza se posebno bavila njegovim člancima „Bužim umire, ali se nada“ i „Uvreda i primitivizam“ objavljenih u Ličkim novinama, člankom „Neznani junak“, objavljenom u Hrvatskom tjedniku i organizacijom sahrane Ivana Šikića Junga, ${ }^{78}$ za kojeg su držali da je tijekom Drugog svjetskog rata bio pripadnik ustaškog pokreta i izraziti nacionalist.

Ivicu Vukića, političkog zatvorenika iz 1966., osuđenog na 6 godina strogog zatvora zbog organizacije udruživanja protiv naroda i države, Analiza je optužila da je „(...) tokom ljeta 1971. godine napadao funkcionere Općinske skupštine Gospić radi toga što Ogranku ne daju prostorije za rad, ne osiguravaju novčana sredstva, kako bi se omogućilo da se lička mladež vaspitava u zdravom duhu i da ne poduzimaju ništa kako bi se spriječilo iseljavanje iz Like ${ }^{\text {“79 }}{ }^{79}$ kontekstu karlobaških prilika Analiza je detaljno opisala djelovanje Mirka Stilinovića, ${ }^{80}$ tadanjeg ravnatelja škole, njegovu korespondenciju sa središnjicom Matice i navodno učlanjivanje malodobne školske djece u njezino članstvo. $U$ taj je opis Stilinovićevih djelatnosti ubrojena i njegova suradnja sa Slobodanom Budakom koji je u to vrijeme, očito u kontekstu Matičinih aktivnosti, držao javna predavanja u Karlobagu koja su proglašena neprijateljskima.

$77 \quad$ Analiza, 1972, 26.

78 Ivan Šikić - Jungo (Podoštra, 1912. - Zagreb, 1971.), začetnik ideje o tunelu kroz Velebit. Radio je u Gospiću kao bankovni činovnik do 1967. kad je umirovljen. Bio je prepoznatljiv član Matice hrvatske, idealist i hrvatski domoljub. (I. MAtaIJA, Šikić, Ivan - Jungo, u: Leksikon Ličana, ur. Ivica Mataija, Gospić, 2017., 283) Matica hrvatska u Gospiću organizirala mu je veličanstven pokop koji je gospićki OK SK proglasio „nacionalističkim ekstremom (...) posebno kad su upotrebili i takve metoda organizacije, da ga kao »velikog junaka i nacionalnog borca « izlažu u Kapeli, a preko lijesa postavljaju hrvatsku trobojnicu. Zatim mu sviraju hrvatsku himnu na grobu (...)“ Analiza, 1972., 27.

79 Analiza, 1972., 28.

80 Zbog te je djelatnosti Mirko Stilinović 5. 3. 1972. isključen iz Saveza komunista, s argumentacijom da je njegov postupak neoprostiv. Komitet je tražio da mu se onemoguće društvene i političke funkcije i da njegov radni status razmotri njegova radna organizacija. Na tom je tragu Okružno javno tužilaštvo u Gospiću protiv njega 8. 11. 1972. podignulo optužnicu pred Okružnim sudom u Gospiću zbog krivičnog djela iz čl. 118. st. 1. KZ-a. Presudom Okružnog suda u Gospiću od 29. 3. 1973. osuđen je na 4 mjeseca zatvora. Ta je presuda poništena odlukom Vrhovnog suda 19. 2.1974. i predmet je vraćen na ponovno suđenje na kojemu je osuđen na 2 mjeseca zatvora, uvjetno na jednu godinu. 
Autori Analize zaključili su kako na području Općine Gospić u predmetnom razdoblju SK, Sindikat, SSRN, Savez omladine, Savez boraca, Savez rezervnih vojnih starješina, Općinska skupština i radne organizacije nisu postali poligon za akciju tzv. masovnog pokreta. Intenzivniji nacionalističko-šovinistički istupi pod utjecajem opozicijskog tiska i drugih sredstava javnog informiranja te političke emigracije javljali su se $u$ istupima pojedinaca i grupa kroz nacionalističkošovinističke pjesme, parole i pojedinačna javna istupanja, a SK reagirao je presporo, a ponekad uopće nije reagirao. Organi gonjenja i pravosudni organi loše su međusobno koordinirali, a u nekim slučajevima, pod utjecajem republičkih institucija (poglavito tužilaštva), ostali su pasivni. O Analizi je Općinska konferencija SK Gospić, uz nazočnost Jakova Blaževića, raspravljala 31. 3. 1972. Na 6. Općinskoj konferenciji SKH Gospić, održanoj 1. 3. 1972., usvojeni su Zaključci o utvrđivanju stupnja političke odgovornosti koje je utvrdio Općinski komitet 10. 5. 1972., a Ličke novine objavile 1. 6. 1972. u 11. broju. U njima je objavljena politička presuda 16 osoba: Ante Rukavine, Mirka Stilinovića, Julija Derossija, Zdravka Vujanića, Mile Domazeta, Marka Kasumovića, Nikole Bićanića, Milorada Čubrila, Stanka Stanića, Ivice Vukića, Nile Devčića, Bogdana Dragaša, Nikole Kneževića, Dušana Vujnovića, Ivana Šutije i Ivana Mesića. Zaključno, Komitet je obvezao „organizacije SK i komuniste u organima javne sigurnosti, tužilaštva i sudova (...) da (...) utvrde stepen pojedinačne odgovornosti, društvene odgovornosti i da u okvirima svoje nadležnosti poduzmu odgovarajuće radnje kako bi se nosioci rušenja (...) podvrgli najstrožim sankcijama“" ${ }^{81}$ Zaključci su bili podloga policijskim i pravosudnim aktivnostima koje su kasnije uslijedile.

Jezična su pitanja, kao segment nacionalističkih nastojanja, s političkog aspekta u Analizi obrađena u poglavlju $O$ nekim negativnim pojavama u školstvu u kojem autori ističu da je „u periodu nacional-šovinističkih pojava na našem području i u oblasti školstva došlo (...) do izvjesnih nejasnoća, kolebanja, uznemirenosti i žustrih rasprava oko nekih dijelova dopunskog programa za osnovne škole, naziva jezika prije nego što su usvojeni Ustavni amandmani na Ustav SRH“. 82

$\mathrm{Na}$ temelju provedenih analiza zaključili su da je u gospićkim školama toga doba očito „bilo nekih rasprava oko naziva jezika, oko precrtavanja pridjeva „srpski“ itd. To je u izvjesnom smislu remetilo i odnose među nastavnim osobljem, jer je precrtavanje pridjeva „srpski“ u nazivu jezika smatrano podcjenjivanjem i jednom teškom uvredom do tada ravnopravnih kolega obiju narodnosti. U

81 Zaključci šeste Općinske konferencije SKH Gospić, Ličke novine, br. 11., 1. 6. 1972.

82 Analiza, 1972., 44. 
pitanja jezika bila je uključena i Stanica javne sigurnosti koja je zabilježila događaj u osnovnoj školi u Kosinju u kojoj je nastavnik jezika objašnjavao djeci da se ubuduće jezik neće zvati hrvatskosrpski, već samo hrvatski. ${ }^{83}$ U razmatranju prosvjetnih prilika autori Analize zaključuju „da je u drugoj polovici 1971., a bilo je pojava i u ovoj godini, da su direktori škola u Gospiću pretežno Srbi, što u dobroj mjeri u pozemlju čini svoje, a izvjesnim građanima služi za kupljenje poena. (...) Na ovome području je Partija znala i danas zna o tome voditi računa, pa će joj i u buduće biti jedan od osnovnih zadataka, da u društveno-političkim organizacijama, (...) vodi politiku razmjerne nacionalne zastupljenosti (...) Prema tome, svaki pokušaj prebrojavanja u buduće i poslije ove Konferencije SK smatrat će se nacionalističkim i tendencioznim pokušajem udara na bratstvo i jedinstvo Hrvata i Srba na ovom području. ${ }^{\text {"84 }}$

\section{ZAKLJUČAK}

Pokušaji reformskih procesa $\mathrm{u}$ duhu hrvatskog proljeća na gospićkom području, kao i na prostoru cijele Hrvatske, donijeli su u tadanji društveni i politički život iznimnu živost, polemičnost, višeglasje, konfrontaciju i na kraju represiju kojom je lokalni SK namjeravao konačno silom riješiti, iza Drugog svjetskog rata, neriješena, poglavito nacionalna pitanja. Upravo su nacionalna pitanja u Lici u tom razdoblju politički instrumentalizirana i u jednom trenutku poslužila konzervativnom centralističko-unitarističkom dijelu SK Hrvatske i Jugoslavije kao povod za napad na tadanje hrvatsko političko vodstvo i reformske procese. Obrazac te instrumentalizacije, utemeljen na tezi o ugroženosti Srba u Lici, ponovit će se s daleko tragičnijim posljedicama i dvadesetak godina kasnije. Najistaknutiji tadanji lički političari na republičkoj i saveznoj razini koji su intenzivno utjecali na ličke političke prilike i politiku SK, predsjednik Sabora Jakov Blažević, član Izvršnog komiteta CK SKH Dušan Dragosavac, predsjednik Republičkog odbora rezervnih starješina general-pukovnik JNA i jugoslavenski narodni heroj Milan Kuprešanin, ali i Titova supruga Jovanka pripadali su konzervativnoj partijskoj frakciji koja je nakon sjednice u Karađorđevu preuzela vodeće uloge u hrvatskom, ali i saveznom političkom životu i bila predvodnica novog partijskog smjera oslonjenog na predreformske društvene i političke vrijednosti i obračun $s$ hrvatskim reformistima.

\footnotetext{
83 Analiza, 1972., 45.

84 Analiza, 1972., 50.
} 
Odjeci hrvatskog proljeća odrazili su se u svim sferama gospićkog društvenog života, pa i u organizacijama koje su najupornije branile tadanju službenu ideologiju, njezinu doktrinu i simbole. Na primjeru gospićkih prilika vrlo je razvidna funkcionalna metodologija vlasti $S K$ i njezina subordiniranost $u$ političkom djelovanju koja i ovim segmentom svjedoči o najvažnijim modelima i instrumentarijima nedemokratske, na komunističkim idejama zasnovane i revolucijom osvojene vlasti. Centralni i lokalni komiteti SK upravljali su svim razinama vlasti i na primjeru događaja iz hrvatskog proljeća svjedočili potpunoj uzurpaciji, demokratskim društvima svojstvene, trodiobe vlasti. Nakon Karađorđeva uslijedila je i u Gospiću unutarpartijska „diferencijacija“ koja je bila neusporedivo blaža nego ona koju je Partija provodila prema drugim ustanovama, institucijama i pojedincima. Kao i u ostalim dijelovima Hrvatske, i u Gospiću su se na njezinu udaru našli ponajprije pojedini članovi Matice hrvatske koji su, osim političkog, bili suočeni i s pravosudnim progonom, a nakon neuspješnih pokušaja da Maticu hrvatsku discipliniraju i odvoje od tih njezinih kontrarevolucionarnih grupa i pojedinaca, i gospićkom je Ogranku zabranjen rad. Silnice djelovanja Partije i cjelokupnog lokalnog državnog aparata bile su usmjerene potiskivanju i razgradnji važnih elemenata ličkog zavičajnog hrvatskog identiteta i jačanju supranacionalnog, jugoslavenskog koji se ogledao i u odnosu prema jeziku, njegovu imenu i javnoj uporabi. 


\section{IZVORI I LITERATURA}

\section{IZVORI:}

Ličke novine, god. XVIII, 1971.

Službeni list FNRJ, god. VII., br. 13, 9. III. 1951.

Državni arhiv u Gospiću (HR DAGS)-42: Okružni sud Gospić, 1944. - 1982.

HR DAGS-90: Međuopćinska konferencija SKH Gospić, 1968. - 1982.

HR DAGS-93: Općinski komitet SK Gospić, 1960. - 1987.

HR DAGS-102: OK SOH Gospić, 1972.

\section{LITERATURA:}

DABČEvić-KuČAR, Savka, '71: hrvatski snovi $i$ stvarnost, Interpublic, Zagreb, 1997.

Derossi, Julije, Čekulade nema - Gospićka ljudikanja, Matica hrvatska Gospić, Gospić, 2007.

DubravicA, Branko, Gospić u socijalističkom razdoblju, u: Gospić - Grad ljudi, identitet, ur. Željko Holjevac, Institut društvenih znanosti Ivo Pilar, Zagreb Gospić, 2013., 217 - 230.

Du kovski, Darko, Istra i Rijeka u Hrvatskome proljeću, Alineja, Zagreb, 2007.

Hrvatsko proljeće. Presuda Partije. Izvještaj o stanju u Savezu komunista Hrvatske u odnosu na prodor nacionalizma u njegove redove, ur. Mirko Mađor, Dom i svijet, Zagreb, 2003.

IvičEvić, Jozo, Matica hrvatska nakon Karađorđeva, u: Nepoznata istina o crnom danu za hrvatske domoljube 11. siječnja 1972. - O udaru na Maticu hrvatsku $i$ hrvatsko proljeće - O Hrvatskoj danas, Zbornik radova, ur. Vlatko Pavletić, Knjižnica „Kritika“, Zagreb, 2002., 94 - 107.

KLASIĆ, Hrvoje, Hrvatsko proljeće u Sisku, Srednja Europa, Zagreb, 2006.

KuČIn IĆ, Tomislav, Himne na tlu Hrvatske u 20. stoljeću, diplomski rad, Muzička akademija Sveučilišta u Zagrebu, Zagreb, 2019.

Leksikon Ličana, ur. Ivica Mataija, Državni arhivu u Gospiću, Gospić, 2017.

Lučıć, Iva, Političke kontroverze o popisu stanovništva 1971. godine, u: Hrvatsko proljeće 40 godina poslije, ur. Tvrtko Jakovina, Centar za demokraciju i pravo Miko Tripalo, Filozofski fakultet Sveučilišta u Zagrebu, Fakultet političkih znanosti Sveučilišta u Zagrebu i Pravni fakultet Sveučilišta u Zagrebu, Zagreb, 2012. 
Mataija, Ivica, Vrcić-Mataija, Sanja, Odjeci Deklaracije o nazivu i položaju hrvatskog književnog jezika na području Gospića, u: Zbornik radova Zadarski filološki dani 7., ur. Rafaela Božić, Sandra Hadžihalilović i Josip Lisac, Sveučilište u Zadru, Zadar, 2019., 49 - 64.

Minaljević, Josip, Liberalizacija 1960-tih godina - podloga hrvatskoga proljeća, u: Zbornik radova Hrvatska i hrvatsko proljeće 1971., ur. Igor Zidić, Matica hrvatska, Zagreb, 2017., 263 - 277.

PASARIĆ, Dragutin, Dah kršne Like - Ogranak Matice hrvatske u Gospiću, Vijenac, br. 420., 7.travnja 2010. https://www.matica.hr/vijenac/420/dahkrsne-like-2238/ (pristupljeno 15. svibnja 2020.).

Ridley, Jasper, Tito - Biografija, Prometej, Zagreb, 2000.

Tripalo, Miko, Hrvatsko proljeće, Globus, Zagreb, 1989.

VUKIĆ, Ivan, Lika i podgorje na braniku doma i naroda, HOR, Zagreb, 2012.

\section{INTERNET IZVORI:}

Derossi, Julije, Otvoreno pismo Matici hrvatskoj, 2012., https://hr.wikisource. org/wiki/Otvoreno_pismo_Julija_Derossija_Matici_hrvatskoj, posjećeno 25. rujna 2019.

„Lijepa naša domovino“ - put od stotinu godina do statusa hrvatske himne, https://www.sabor.hr/hr/o-saboru/povijest-saborovanja/zanimljivosti/ lijepa-nasa-domovino-put-od-stotinu-godina-do-statusa, posjećeno 19. 5. 2020. 
Ivica MATAIJA

Sanja VRCIĆ-MATAIJA

\section{THE CROATIAN SPRING IN GOSPIĆ}

\section{SUMMARY}

Based on available archival material, newspaper articles and reference literature, the paper investigates and analyses the social and political situation in Gospić during the Croatian Spring. After the Second World War, there were unresolved national issues, as well as economic, communal and infrastructural stagnation in the late 1960s and early 1970s. Also, the domination of the imposed supranational identity and symbols and the consequent restraint and marginalisation of the fundamental values of Croatian tradition, cultural and linguistic status caused an ever-increasing tension in the social and political life of Gospić. Under careful scrutiny came activities of local Communist League organisations who, being the creators of entire social life, faced significant difficulties. Also, their decisions, based on the doctrine of brotherhood and unity and revolutionary communist ideology on the political principle of democratic centralism, drastically affected many institutions and individuals who occupied an essential place in the then social life of Gospić. The period of the Croatian Spring in Gospić was marked by constant and intense turmoil on several levels. Within the League of Communists themselves, the reformist currents of politics of the Central Committee of the SKH (LCC) and Savka Dabčević Kučar, and the conservative, unionist ones, relying on the policy of the SKJ ( LCY) and Josip Broz Tito, came into conflict with each other. Reformist currents also affected other socio-political organisations of that time, especially the most massive SSRN. This institution was a very lively interpreter and implementer of the then important social issues such as changing the constitution, conducting a census and, after the Declaration, again very current, language issues. Particular focus was placed on the Gospić Branch of Matica Hrvatska and several of its prominent members. In the process of discovering the main initiators of nationalism and chauvinism, they were denounced as its main originators and bearers. After Karađorđevo Meeting, according to a clearly established pattern methodologically developed by the top of the SKJ (LCY) and SKH LCC), the process of dealing with nationalism began, which in various ways included numerous individuals and institutions, especially the Matica Hrvatska branch in Gospić, and the Medak Board of Education, which were banned. Following the instructions of their party headquarters, the Gospić communists, emphasising 
their position of power, reacted to domestic social and political circumstances by taking repressive measures. They were aimed at undesirable contents and influential personalities of prominent national identity who raised the level of the social and cultural life of Lika.

Keywords: Croatian Spring, League of Communists, Gospić, Matica Hrvatska, Analysis, language issues. 
